\title{
Disease Control for Florida Tomatoes ${ }^{1}$
}

\author{
Mathews Paret, Ken Pernezny, and Pam Roberts ${ }^{2}$
}

\section{Introduction}

Fresh-market tomato is the most valuable vegetable crop in Florida. In 2012, 29,000 acres of tomatoes were commercially harvested in the state with a production value of nearly $\$ 268$ million (USDA 2013).

Tomatoes are grown throughout the state, with commercial production centered in five locations: Miami-Dade County (Homestead), Palm Beach/St. Lucie Counties, southwest Florida (Immokalee/Naples), Manatee/Hillsborough Counties (Ruskin), and northwest Florida (Quincy). Most of these are fresh-market tomatoes produced from September to June.

Successful disease management has always been vital in Florida tomato production, given the generally ideal environmental conditions for most plant diseases. An integrated disease management program is a successful approach.

\section{Tomato Pathogens}

The majority of plant problems that we call diseases are caused by pathogenic microorganisms. These extremely tiny disease agents cause losses by attacking the tomato fruit directly, rendering them unfit for consumption, or sufficiently detracting from their appearance to reduce consumer preference. They also affect other plant parts, reducing plant vigor and carbohydrate production and incurring subsequent yield and monetary losses.

The pathogens attacking tomato can be classified into three major groups: fungi and fungal-like organisms (hereafter referred to as fungal-like), bacteria, and viruses.

\section{Fungi}

Fungi are microscopic organisms that are commonly classified as resembling plants. However, they are sufficiently different from plants that experts now classify fungi in a unique category. They have no true leaves, roots, or stems. Instead, they appear as hyphae (microscopic threads) that absorb food and water into their cells. Although fungi have cell walls like plants, the chemicals composing the wall are not predominantly cellulose, as in higher plants. Because fungi have no chlorophyll, they must depend on outside sources of food, including living plants.

Many of the fungi attacking tomatoes reproduce by creating large numbers of spores. Some spores are borne by wind or moisture and spread readily within and between fields. Some fungi, especially those causing wilt and root diseases, can survive one or more years between susceptible crops with the aid of thick-walled spores or sclerotia (aggregates of hyphae).

1. This document is PPP35, one of a series of the Plant Pathology Department, UF/IFAS Extension. Original publication date February 2008. Revised June 2013. Visit the EDIS website at http://edis.ifas.ufl.edu.

2. Mathews Paret, assistant professor, Plant Pathology Department, North Florida Research and Education Center - Quincy; Ken Pernezny, professor, Plant Pathology Department, Everglades Research and Education Center - Belle Glade; and Pam Roberts, associate professor, Plant Pathology Department, Southwest Florida Research and Education Center - Immokalee; UF/IFAS Extension, Gainesville, 32611.

The use of trade names in this publication is solely for the purpose of providing specific information. UF/IFAS does not guarantee or warranty the products named, and references to them in this publication does not signify our approval to the exclusion of other products of suitable composition. All chemicals should be used in accordance with directions on the manufacturer's label. 
Fungi may enter plants through wounds or natural openings (e.g., the stomates that allow normal exchange of oxygen and carbon dioxide between the plant cells and the atmosphere). Some can also penetrate directly through the cuticle and cell walls.

\section{Oomycetes (Fungal-Like Organisms)}

Oomycetes are commonly referred to as "water molds" or "fungal-like" organisms. Although formerly classified as fungi, members of this class were taxonomically reclassified when they were shown to be distinct from fungi through comparative genomics (Fry and Grünwald 2010). Oomycetes are different from fungi in some key characteristics. For example, their cell walls are made of cellulose, whereas the cell walls of true fungi are composed of chitin. As the name "water molds" implies, many in this group favor wet conditions, and the spores that they produce, called zoospores, are capable of swimming and use plant-produced chemical cues to reach and infect their host. Because of these fundamental biological and physiological differences, management of oomycete diseases like those caused by Phytophthora and Pythium spp. requires its own set of control measures.

\section{Bacteria}

Bacteria are smaller microorganisms than fungi. They are single celled, and the ones that cause plant disease do not form spores. Simple cell division is the main known type of reproduction for plant pathogenic bacteria. They are not known to penetrate the plant directly but must have a wound or natural opening to get inside a potential host plant. Bacteria cause some of the most serious Florida tomato diseases.

\section{Viruses}

Viruses should not be considered organisms. They are simply molecules made of a nucleic acid (DNA or RNA) with a "wrapping" of protein and have no cellular structures. New virus particles can only be synthesized within living plant cells. They are much smaller than bacteria and normally require the high magnification of an electron microscope to be seen. Most of the important tomato viruses are transmitted from tomato and wild hosts (such as black nightshade) to tomato by aphids, whiteflies, and thrips. A few viruses are spread mechanically.

\section{Basic characteristics of tomato diseases}

For a disease to occur in tomato plants, all three components of the "disease triangle" are required: a virulent pathogen, a susceptible variety, and weather conditions favorable for the disease. If any one of these components is missing, plants will not become diseased.

Effective tomato disease control is based on understanding the biology of the causal organism, the response of the host to this pathogen, and the interplay of outside physical forces, such as temperature and soil type on the living systems involved. Characteristics of the major Florida tomato diseases are listed in Table 1.

\section{Suggested Sequential Program for Disease Control}

\section{Soil Fumigation}

Most Florida tomatoes are now produced using the full-bed fumigation, plastic-mulch system. Fumigants are volatile broad-spectrum biocides that can be applied to the soil. During a period of exposure, they can effectively control many potentially harmful disease agents, especially fungi. Most of the organisms that survive well in the soil (Table 1) can be managed if fumigants are properly applied prior to planting. In addition, broad-spectrum fumigants or other combinations of fumigants and materials used in conjunction can destroy other pests, including nematodes, soil insects, and weed seed.

The fumigants must thoroughly penetrate the spaces between soil particles. Since crop residues can interfere with fumigant penetration, they must be worked into the soil and allowed to decompose before fumigation.

\section{Host Resistance}

Choose varieties with disease resistance. Using diseaseresistant plants can reduce the amount of pesticides required to produce quality fruit and economic returns. Knowing which diseases are present in production areas or knowing the disease history within a particular field can help determine the resistance needed. This method makes it possible to attain practical control of many diseases. Disease resistance must be considered as important a factor in variety selection as fruit quality, yield, and other horticultural traits if a farmer is to be successful growing tomatoes in Florida. 


\section{Specific Cultural Control Measures}

The use of plastic mulch is a very important cultural control for fruit rots in the field. Soil rot (Rhizoctonia solani) and buckeye rot (Phytophthora parasitica) are two soilborne pathogens that caused great losses before plastic mulch was used to prevent contact between fruit and the soil. Staking plants has also reduced losses from fruit rots.

Production of disease-free transplants is a very important measure for control of many serious problems, especially early blight, late blight, bacterial spot, and several viruses. Use of certified "pathogen-free" seed is also important for some diseases, such as tomato mosaic and bacterial spot.

Destruction of volunteer plants is an important practice in the control of several diseases because it prevents large populations of pathogens from surviving from one crop to another. Crop rotation also works to prevent crop-to-crop survival of specific tomato pathogens.

Upward adjustment of soil $\mathbf{p H}$ by liming is an effective management strategy for Botrytis gray mold on sandy soils. A pH of 6.5-7.0 is recommended for Fusarium wilt suppression.

Choice of planting date continues to be a largely economic decision based on anticipated market "windows" for a given production region. However, controlling a disease by planting date may be considered if a particular problem does not lend itself well to other control measures. Late blight, Sclerotinia stem rot, and leaf mold are cool-weather diseases; while others, such as bacterial spot, southern blight, and bacterial wilt, occur primarily in warm weather. If the actual planting dates can't be used as a primary control strategy, the grower should be aware of the relationship between environmental conditions and certain diseases and apply measures in accord with the prevailing conditions.

Excessive handling of plants, such as thinning, pruning and tying, may help spread some diseases, including bacterial spot, tomato mosaic, and bacterial speck. Whenever possible, plants should be handled and harvested when they are driest. If used, stakes should be decontaminated. Farm equipment should also be periodically decontaminated to reduce between-field pathogen spread.

Several experiments have also shown that overhead irrigation aggravates disease problems, especially those caused by bacteria. Well water is preferred for spraying because stream water may be contaminated with pathogens.
Rapid crop destruction at the end of the season is crucial for managing tomato yellow leaf curl virus (TYLCV). It is extremely important that crops be destroyed immediately after harvest because this reduces areas where whiteflies can build up and move to new crops. Rapid crop destruction, especially for those crops infected with diseases, can prevent spread of many pathogens.

Manage and remove weeds that can serve as sources of inoculum for viruses and other pathogens during production and the off-season.

\section{Foliar Fungicide and Stylet Oil Application}

Periodic fungicide application is an important component of current tomato disease control programs. Ground applications are typically used for good canopy penetration and coverage of leaf undersurfaces. Attention to the application technique is as important as choice of material for achieving adequate disease control. A "typical" tomato spray application uses a tractor-mounted boom sprayer at 200-275 psi pressure and 100 gal./acre of finished spray on mature plants. Proper application calibration should result in tractor speed of about 3 miles/hour. At this speed, an observer should be able to walk behind the tractor at a comfortable pace. If the tractor speed is properly adjusted, most diseases can be adequately controlled with one application of fungicide per week. Faster tractor speeds can lead to poor control and may make more frequent applications necessary. Care must be taken to ensure that nozzles work properly, strainers are clear, and nozzle arrangement allows for adequate coverage. Tomato growers should start adding drop nozzles early (certainly by first bloom). The air in the tomato canopy must be completely displaced by a fine mist of fungicide to prevent disease outbreaks that can begin from deep inside.

Fungicides are primarily preventative: They must be applied before the pathogen arrives on the foliage to have effective disease control. Timing of the sprays is very important. If fungicide sprays are started after the disease is discovered, it may be impossible to curb an epidemic. This is particularly true for late blight. Experiments have shown that even when fields are scouted closely on a regular basis, spray programs initiated after the first detection of late blight do not prevent severe economic loss.

Chlorothalonil, mancozeb, or maneb offer the most broad-spectrum activity against the common tomato foliar fungal diseases: late blight, early blight, and target spot. The Quinone outside inhibitors (QoI) group of fungicides containing strobilurins offers a broad spectrum of activity. 
Recently, there are new fungicide choices for oomycete control, including control of late blight and damping-off. A formulation of mefanoxam (or metalaxyl) can be applied to control damping-off caused by Pythium spp., and undervine applications can be made 4-12 weeks before harvest to reduce fruit and root rot caused by Pythium spp. and Phytophthora spp.

When choosing a fungicide, follow resistance management guidelines on the label.

Copper and mancozeb are recommended for bacterial spot control. When the weather conditions favor bacterial spot, growers may have to use this tank mix as their primary "fungicide." Additionally, the systemic acquired resistance inducer, acibenzolar-S-methyl, assists with reducing bacterial spot severity. Realistically, chemical control cannot be expected to be as effective for bacterial diseases as it is for fungal diseases. In fact, if conditions are particularly favorable, frequent applications may not be sufficient to maintain bacterial disease below damaging levels. When used excessively, copper compounds may also retard plant growth and cause copper "stain" on fruit.

\section{While a tank mix of copper and mancozeb has more} bactericidal activity than copper alone (Marco and Stall 1983), this tank mix is less effective than mancozeb alone against several fungal pathogens. This presents particular problems when late blight or target spot is a threat at the same time as a bacterial disease (as occurs during occasional bacterial speck epidemics). In such cases, additional fungicides may need to be sprayed to control these other diseases, such as target spot. Early blight is one foliar fungal disease that historically was quite adequately controlled by applications of copper/mancozeb tank mixes. Growers should consult the University of Florida Vegetable Production Handbook for current, specific fungicide recommendations found in the chapter "Tomato Production in Florida" (http://edis.ifas.ufl.edu/cv137) (Olson et al. 2012).

Management of aphid-transmitted viral diseases (including potato virus $Y$, tobacco etch virus, and tomato yellow virus) by insecticide alone is generally poor. All these viruses are carried on the stylet (feeding probe) of the aphid and are transmitted to the tomato plants at the same time that a lethal dose of insecticide is being ingested by the aphid.

JMS stylet oil, a high-grade petroleum oil, has shown promise in protecting several vegetables, including tomato, from aphid-transmitted virus diseases. A thin layer of this oil on the plant surface apparently serves to inactivate the virus as the aphid probes through the cuticle.

\section{Whitefly-Transmitted Viruses}

In recent years, devastating outbreaks of a group of viruses - the "gemini" viruses and begomoviruses-have occurred in most Florida tomato-growing areas. The major virus problems in this group have been identified as TYLCV and tomato mottle virus. These viruses are transmitted to healthy plants by the silverleaf whitefly. Great progress has been made in the control of these diseases through a sound integrated management program. It is extremely important that crops be destroyed immediately after harvest, as this reduces areas where whiteflies can build up and move to new crops. Weeds and volunteer tomato plants that can serve as hosts for whiteflies should be eliminated. Symptomatic plants within a field should be rogued immediately. A systemic insecticide, imidacloprid, can be applied prior to planting and provides good early season control of silverleaf whitefly. Metalized mulch that reflects UV light is effective in disorienting whiteflies and protecting young plants.

Thrips transmits tomato spotted wilt virus (TSWV) (Funderburk et al. 2011) and the closely related groundnut ringspot virus (GRSV). TSWV can be a damaging disease, and GRSV has been found with increasing incidence since 2009 (Webster et al. 2010). Management of these viruses is difficult, but TSWV-resistant varieties and metalized mulch have been effective for tomato spotted wilt management.

\section{References}

Fry, W. E., and N. J. Grünwald. 2010. "Introduction to Oomycetes." The Plant Health Instructor. doi:10.1094/ PHI-I-2010-1207-01.

Funderburk J., S. Reitz, S. M. Olson, P. Stansly, H. Smith, G. McAvoy, O. Demirozer, C. Snodgrass, M. L. Paret, and N. Leppla. 2011. Managing Thrips and Tospoviruses in Tomato. ENY859. Gainesville: University of Florida Institute of Food and Agricultural Sciences. http://edis.ifas.ufl.edu/in895.

Marco, G. M., and R. E. Stall. 1983. "Control of Bacterial Spot of Pepper Initiated by Strains of Xanthomonas campestris pv. vesicatoria That Differ in Sensitivity to Copper." Plant Dis. 67: 779-781.

Olson S. M ., P. J. Dittmar, G. E. Vallad, S. E. Webb, S. A. Smith, E. J. McAvoy, B. M. Santos, and M. OzoresHampton. 2012. Tomato Production in Florida. HS739. Gainesville: University of Florida Institute of Food and Agricultural Sciences. http://edis.ifas.ufl.edu/cv137. 
United States Department of Agriculture (USDA). 2013.

"Vegetables: 2012 Summary." http://usda01.library.

cornell.edu/usda/nass/VegeSumm//2010s/2013/Vege-

Summ-01-29-2013.pdf.

Webster, C. G., K. L. Perry, X. Lu, L. Horsman, G. Frantz, C.

Mellinger, and S. Adkins. 2010. "First Report of Groundnut

Ringspot Virus Infecting Tomato in South Florida." Plant

Health Progress doi:10.1094/PHP-2010-0707-010BR. 
Table 1. Some characteristics of principal tomato diseases in Florida ${ }^{1}$

\begin{tabular}{|c|c|c|c|c|c|c|c|c|}
\hline Diseases & Pathogen & Organism & $\begin{array}{l}\text { Seed } \\
\text { trans- } \\
\text { mission }\end{array}$ & $\begin{array}{c}\text { Soil } \\
\text { survival }\end{array}$ & $\begin{array}{l}\text { Insect } \\
\text { trans- } \\
\text { mission }\end{array}$ & $\begin{array}{l}\text { Available } \\
\text { resistance }\end{array}$ & $\begin{array}{l}\text { Favorable } \\
\text { conditions }^{2}\end{array}$ & $\begin{array}{l}\text { Areas most } \\
\text { likely to occur }\end{array}$ \\
\hline Bacterial speck & $\begin{array}{c}\text { Pseudomonas } \\
\text { syringae pv. tomato }\end{array}$ & Bacterium & ++ & + & - & - & $C, R$ & ALL \\
\hline Bacterial spot & $\begin{array}{c}\text { Xanthomonas } \\
\text { vesicatoria and } X \text {. } \\
\text { perforans }\end{array}$ & Bacterium & + & + & - & - & $\mathrm{H}, \mathrm{R}$ & ALL \\
\hline $\begin{array}{l}\text { Botrytis gray } \\
\text { mold }\end{array}$ & Botrytis cinerea & Fungus & - & + & + & - & $C, R$ & Sandlands \\
\hline Buckeye rot & $\begin{array}{l}\text { Phytophthora } \\
\text { parasitica }\end{array}$ & Fungal-like & - & ++ & - & - & $H, R$ & ALL \\
\hline Damping-off & $\begin{array}{c}\text { Pythium spp., } \\
\text { Rhizoctonia spp., } \\
\text { Phytophthora spp. }\end{array}$ & $\begin{array}{l}\text { Fungal-like } \\
\text { and fungus }\end{array}$ & - & ++ & - & - & $\mathrm{H}, \mathrm{R}$ & ALL \\
\hline $\begin{array}{l}\text { Double virus } \\
\text { streak }\end{array}$ & $\begin{array}{c}\text { Potato virus } X \text { plus } \\
\text { tobacco mosaic } \\
\text { virus }\end{array}$ & Viruses & + & + & - & + & C & ALL \\
\hline Early blight & Alternaria solani & Fungus & - & - & - & + & $\mathrm{H}, \mathrm{R}$ & ALL \\
\hline Fusarium wilt & $\begin{array}{l}\text { Fusarium oxysporum } \\
\text { f. sp. lycopersici }\end{array}$ & Fungus & - & ++ & - & ++ & $\mathrm{H}$ & Sandlands \\
\hline $\begin{array}{l}\text { Fusarium crown } \\
\text { rot }\end{array}$ & $\begin{array}{c}\text { Fusarium oxysporum } \\
\text { f. sp. radicis- } \\
\text { lycopersici }\end{array}$ & Fungus & - & + & - & ++ & C & Sandlands \\
\hline Gray leaf spot & Stemphyllium solani & Fungus & - & + & - & ++ & $\mathrm{R}$ & ALL \\
\hline $\begin{array}{l}\text { Groundnut } \\
\text { ringspot }\end{array}$ & $\begin{array}{c}\text { Groundnut ringspot } \\
\text { virus }\end{array}$ & Virus & - & - & + & - & $\mathrm{H}$ & $\begin{array}{l}\text { Central and } \\
\text { South Florida }\end{array}$ \\
\hline Late blight & $\begin{array}{l}\text { Phytophthora } \\
\text { infestans }\end{array}$ & Fungal-like & - & - & ++ & - & $\mathrm{C}, \mathrm{R}$ & ALL \\
\hline Pseudocurly top & $\begin{array}{l}\text { Pseudocurly top } \\
\text { virus }\end{array}$ & Virus & - & - & ++ & - & $\mathrm{H}$ & $A L L$ \\
\hline $\begin{array}{l}\text { Potato virus } Y \\
\text { (vein-banding } \\
\text { virus) }\end{array}$ & Potato virus $Y$ & Virus & - & - & ++ & - & $\mathrm{C}$ & East coast \\
\hline $\begin{array}{l}\text { Sclerotinia stem } \\
\text { rot (white mold) }\end{array}$ & $\begin{array}{l}\text { Sclerotinia } \\
\text { sclerotiorum }\end{array}$ & Fungus & - & ++ & - & - & $C, R$ & Miami-Dade \\
\hline Soil rot & Rhizoctonia solani & Fungus & - & ++ & - & - & $\mathrm{H}, \mathrm{R}$ & ALL \\
\hline $\begin{array}{c}\text { Southern } \\
\text { bacterial wilt }\end{array}$ & $\begin{array}{c}\text { Ralstonia } \\
\text { solanacearum }\end{array}$ & Bacterium & - & ++ & - & - & $\mathrm{H}$ & Sandlands \\
\hline Southern blight & Sclerotium rolfsii & Fungus & - & ++ & - & - & $\mathrm{H}$ & Sandlands \\
\hline Target spot & $\begin{array}{l}\text { Corynespora } \\
\text { cassiicola }\end{array}$ & Fungus & - & - & - & - & $\mathrm{R}$ & Sandlands \\
\hline Tobacco etch & Tobacco etch virus & Virus & - & - & ++ & - & C & East coast \\
\hline $\begin{array}{l}\text { Tomato pith } \\
\text { necrosis }\end{array}$ & $\begin{array}{l}\text { Pseudomonas } \\
\text { corrugata }\end{array}$ & Bacterium & - & + & - & - & $\mathrm{C}$ & $\begin{array}{l}\text { ALL - Heavy } \\
\text { nitrogen rates } \\
\text { contribute to } \\
\text { disease }\end{array}$ \\
\hline Tomato mosaic & $\begin{array}{c}\text { Tobacco mosaic } \\
\text { virus }\end{array}$ & Virus & + & + & $+^{*}$ & + & - & ALL \\
\hline $\begin{array}{c}\text { Tomato spotted } \\
\text { wilt }\end{array}$ & $\begin{array}{c}\text { Tomato spotted wilt } \\
\text { virus }\end{array}$ & Virus & - & - & ++ & - & $\mathrm{H}$ & North Florida \\
\hline
\end{tabular}


Archival copy: for current recommendations see http://edis.ifas.ufl.edu or your local extension office.

\begin{tabular}{|c|c|c|c|c|c|c|c|c|}
\hline $\begin{array}{l}\text { Tomato yellow } \\
\text { leaf curl }\end{array}$ & $\begin{array}{c}\text { Tomato yellow leaf } \\
\text { curl virus }\end{array}$ & Virus & - & - & ++ & + & $\mathrm{C}, \mathrm{H}$ & ALL \\
\hline Verticillium wilt & $\begin{array}{l}\text { Verticillium albo- } \\
\text { atrum and V. dahliae }\end{array}$ & Fungus & - & ++ & - & ++ & $\mathrm{C}$ & Miami-Dade \\
\hline \multicolumn{9}{|c|}{$\begin{array}{l}\text { 1+ = may occur occasionally, of some importance. } \\
++=\text { occurs often, important to know for proper control. } \\
-=\text { not known to occur or relatively unimportant. } \\
{ }^{2} \mathrm{H}=\text { warm weather; } \mathrm{C}=\text { cool weather; } \mathrm{R}=\text { favored by extended rainfall. } \\
{ }^{*} \text { Possibly transmitted by insects with chewing mouthparts. } \\
\text { Note: A picture database of tomato diseases can be found in the U-scout of the University of Florida: http://nfrec.ifas.ufl.edu/paret/u-scout/ } \\
\text { Tomato/Tomato.html }\end{array}$} \\
\hline
\end{tabular}

